\title{
ЖАНР МОТЕТА: \\ НЕКОТОРЫЕ ВОПРОСЫ ЭВОЛЮЦИИ И СПЕЦИФИКИ
}

\author{
Минифаева Анастасия Романовна \\ Научный руководитель: Орлова Татьяна Сергеевна \\ к.П.н., доцент \\ Волгоградская консерватория имени П.А. Серебрякова
}

Аннотация: В статье рассматриваются некоторые специфические особенности жанра мотета, затрагиваются вопросы строения, роли тенора в построении композиции, а также эволюция данного жанра.

Ключевые слова: тенор, ars antiqua, ars nova, cantus firmus.

\section{MOTET GENRE: SOME ISSUES OF EVOLUTION AND SPECIFICS}

Abstract: The article considers some specific features of the motet genre, addresses the issues of structure, the role of the tenor in the construction of the composition, as well as the development of this genre.

Key words: tenor, ars antiqua, ars nova, cantus firmus.

В развитии западноевропейской профессиональной музыки мотет является одним из старейших жанров. Его история начинается с XII века, а кульминационным временем принято считать XV-XVI века, когда жанр получил особые варианты трактовки и стал формой, пользующейся повышенным вниманием в творчестве представителей самых разных композиторских школ. Н.А. Симакова называет мотет среди немногих жанров, в которых складываются и отрабатываются лучшие находки и достижения эпохи [6].

За время своего становления мотет представал в самых разнообразных вариантах: так, по содержанию он мог быть сочинением духовным и светским; по характеру исполнения - вокальным или вокально-инструментальным. Что касается литературных источников, то мотет мог быть написан на один или несколько текстов, при этом иногда на разных языках с различным содержанием. 
По мнению исследователей (Н.А. Симакова, Ю.К. Евдокимова, Т.Н. Дубравская и др.), одной из причин столь разнообразного и свободного применения мотетов связана с тем, что, в отличие от других жанров эпохи, в частности, важнейшего жанра - мессы, - в мотете не было строгих предписаний, касающихся содержания и места исполнения. Однако, такая свободная трактовка жанра появилась со временем, тогда как на начальных этапах мотет имел четко обозначенные и ярко выделяющие его среди других жанров специфические особенности.

Говоря о названии жанра, следует отметить, что оно происходит от французского слова «mot» и в переводе означает «слово». Голос, где впервые по сравнению с инструментальной строчкой, ведущей основной напев, появился текст, стал называться мотетус. Отсюда и название. Помимо данной трактовки существует и другая: от «motus», что означает «движение». Ведущим голосом в мотете, где помещался основной напев, был тенор (от «teneo», что в переводе означает «держать»).

Исследователи подчеркивают, что сочинение композиции начиналось с тенора. Один из вариантов сочинения раннего мотета мог быть таким: «Возьми тенор из антифонария... изукрась его и дай мензуру...когда он будет хорошо размеренным, сделай над ним дискант...после этого приладь над мотетом триплум, как умеешь и можешь лучше» [5, С. 96].

Тенор мог иметь различные варианты, которые заключались в следующих моментах:

- в выборе ритмического модуса (это мог быть любой из существовавших в то время шести модусов, кроме последнего).

- в выборе ordo (количество соединенных в одной мелодической фразе фигур ритмических модусов).

- в протяженности мелодической остинатной фразы, которая могла быть различной [3].

К уже имеющемуся тенору сверху надстраивались другие голоса: дуплум (или мотетус), триплум, квадруплум (в четырехголосных композициях). Таким образом, композиция осуществлялась аддитивным методом.

Следует отметить, что аналогичным способом происходило сочинение двух более ранних жанров, являющихся предшественниками мотета органума и клаузулы, когда основная тема песнопения католической службы перешла от верхнего голоса к нижнему (тенору), над партией которого импровизировался дискант. 


\section{СИНТЕЗ МЕЖДИСЦИПЛИНАРНОГО НАУЧНОГО ЗНАНИЯ КАК ФАКТОР РАЗВИТИЯ СОВРЕМЕННОЙ НАУКИ}

Органум, как одна из наиболее сложных и развитых форм высокого Средневековья, содержал в себе разнообразные варианты технических приемов работы с cantus firmus, впоследствии реализуемый в мотетах. Один из важнейших композиционных принципов позднего органума заключался в продлении звучания cantus firmus посредством остинатного повторения мелодических отрезков тенора, и, как следствие, увеличение масштабов музыкальной композиции. Органум был единственной по сравнению с клаузулой музыкальной формой, где cantus firmus звучал целиком. Их тех разделов органума, где cantus firmus ритмизовался, в XIII веке возникли клаузулы как самостоятельные композиции [3].

Именно этот принцип составил основу мотета XIII века и наиболее сложного его вида - изоритмического мотета XIV века.

В своем развитии мотет прошел несколько этапов, начиная с XII-XIII веков и завершая XIV-XV веками, хотя жанр оказался настолько актуальным, что его образцы можно найти вплоть до XX века. В это время появление мотета связано с попытками обновления церковной музыки, когда создавались особые духовные мотеты, в которых традиции доклассической музыки сочетались с применением совершенно новых средств музыкальной выразительности. Данный вид мотета можно встретить в творчестве И. Давида, Й. Дистлера, Э. Пеппинга и др.

В рассматриваемой нами эпохе (XIII-XV в.в.) в эволюции мотета прослеживаются два важнейших этапа: ars antiqua и ars nova. Начиная с XIII века, мотет находился в центре многоголосного искусства, хотя вплоть до конца столетия продолжали существовать органумы и кондукты.

Возникнув на основе органумов и клаузул, мотет в то же время представляет собой новое явление, существенно отличаясь от своих предшественников.

Далее считаем необходимым выделить черты, отличающие мотет XIII века от кондуктов и органумов:

- более скромные масштабы, в противоположность длинным по времени органумам и кондуктам;

- отсутствие виртуозной техники полифонического многоголосия органумов, значительное сужение приемов письма. В мотетах преобладает полимелодическое многоголосие;

- выдвижение небольших вариантов - остинатных форм мотетов, в сравнении с развернутыми формами сложных кондкутов; 
- отход от четырехголосного письма, «классический» мотет ars antiqua (эпохи Франка Кельнского) - трехголосный мотет.

Мотет эпохи ars antiqua характеризуется рядом особенностей:

- модальная ритмика на стадии перехода к мензуральной, разнотекстовость в многоголосии (мотеты писались на разных языках, чаще всего на латинском и французском) [3];

- принцип горизонтального, линейного складывания музыкальной ткани;

- построение композиции на основе остинатно-вариационных закономерностей, связанных со строением текста.

Важнейшим показателем мотетной композиции являлся тенор. На протяжении всего XIII века теноровый репертуар мотетов заимствовался прежде всего из «Magnus Liber organi» (так называемая «Великая книга органума», написанная на латыни, и содержащая репертуар средневековой музыки. Эта книга использовалась композиторами школы Нотр-Дам, работавшими в Париже в конце XII-начале XIII веков).

Следует подчеркнуть, что тенор мотетов брался из мелизматических фрагментов песнопений, с соответствующим текстом. В данном случае тенор не обладал самостоятельной выразительностью, являясь исключительно конструктивным элементом композиции.

Специфическим признаком мотета XIII века является мелодическая и ритмическая остинатность тенора, т.е. в это время устанавливался определенный канон работы с общим принципом cantus firmus, выбранного в качестве тенора мотета.

Таким образом, тенор являлся основой композиции, задавая общую форму, так как количество повторений фрагмента выбранной мелодии тенора определяло количество разделов в мотете.

Остальные голоса в мотете сочинялись по горизонтальному принципу, т.е. мелодическими линиями, поэтому основной проблемой в создании жанра была проблема полимелодической полифонии. При этом важную роль играло соотношение голосов по вертикали. Франко Кельнский в трактате «Ars cantus mensurabilis» писал о том, что для правильного сочинения мотета необходимо учитывать движение всех голосов, чтобы они правильно сочетались гармонически [6].

Что касается ритмики, то она также отражает своеобразие и эволюцию мотетных композиций на протяжении XIII века. Здесь можно выделить две тенденции: 


\section{СИНТЕЗ МЕЖДИСЦИПЛИНАРНОГО НАУЧНОГО ЗНАНИЯ КАК ФАКТОР РАЗВИТИЯ СОВРЕМЕННОЙ НАУКИ}

1. Мотеты, представляющие ритмику в старой модальной системе;

2. Ранняя стадия мензуральной ритмики.

В целом практика мотетов XIII века - практика приспособления модусных формул к условиям мензуральной ритмики.

Наиболее строго модусной системе следует тенор, в противоположность которому в верхних голосах (прежде всего - в триплуме) ритмика трансформируется.

Особую группу того периода составляют мотеты, где верхний голос являлся наиболее подвижным и возглавлял ткань, в то время, как нижние голоса поддерживали его мелодическими контрапунктами. Стиль подобных мотетов называют «триплум-стилем», что указывает на ведущее значение триплума. Этот стиль характеризует поздний этап развития мотета ars antiqua (80-е - 90-е г.г. ХІІІ века).

В последней трети XIII века появляется особая разновидность мотета жанры, в которых все голоса имели французские тексты и песенные мелодии в основе. Эти мотеты представляли собой так называемые мотеты ente (т.е. возникшие на светскую песенную мелодию). Даже в теноре чаще используется французский, а не латынь. В связи с активным включением светских элементов мелодия тенора заимствуется из светских песенных форм, поэтому ее строение подчиняется не принципу остинатности, а закономерностям мелодических структур светских песенных форм. Эта группа мотетов занимает промежуточное положение между мотетами ars antiqua и многоголосными светскими композициями эпохи ars nova. Появление светского напева в теноре означало полную секуляризацию жанра [3].

Таким образом, в XIII веке сложилась четкая специфика стиля, связанная с жанром мотета. Сформировавшиеся законы композиции и приемы письма в этом жанре настолько утвердились, что на фоне искусства старой традиции (органум, кондукт), а также на фоне появившихся в конце века светских многоголосных жанров мотет ярко выделяется, приобретая характерные черты.

B эпоху ars nova в системе музыкальных жанров происходят заметные преобразования. Так, на первое место выдвигаются жанры песенного многоголосия - рондо, баллаты, виреле, мадригалы. Жанр мотета в это время достигает новых вершин. Прежде всего изменения касаются ритмической организации жанра. Появляется изоритмия как важнейший принцип композиции ars nova. Для изоритмических композиций характерными являются следующие черты: 
- разделение фактуры на ритмоинтонационные ярусы, где верхние голоса являлись более подвижными и развитыми, а тенор «работал» на контрасте в плане ритма и звуковысотности;

- возрастание роли пауз, которые становятся более протяженными. Во время паузирования тенора в мотет включались имитации.

В развитии мотета исследователи отмечают особую роль Ф. де Витри, Г. де Машо, Дж. Данстейбла, Дж. П. Палестрины, А. Вилларта, И. Чакониа и др.

В заключении отметим, что общий вектор развития жанра мотета направлен в сторону усложнения, детализации, достижению кульминации ритмической и фактурной сложности, а затем - наоборот - к упрощению письма, прояснению фактуры и формированию основ нового стилевого направления, получившего развитие в рамках бургундской школы («новый стиль»).

Следует подчеркнуть, что история развития мотета демонстрирует большие возможности этого жанра и его широкое применение в творчестве представителей самых разных композиторских школ.

\section{Список литературы}

1. Грубер Р.И. Всеобщая история музыки. - М. -1965 .

2. Гуревич А.Я. Категории средневековой культуры. - М. - 1972.

3. Евдокимова Ю. Многоголосие Средневековья. X-XIV века // История полифонии. Вып. 1. - М. - 1983.

4. Евдокимова Ю.К., Симакова Н.А. Музыка эпохи Возрождения. - М. 1982.

5. Ливанова Т.Н. История западноевропейской музыки до 1789 года. M. -1940 .

6. Симакова Н. Вокальные жанры эпохи Возрождения.- Изд. 2-е. - М. 2002.

7. Сапонов М.А. Мензуральная ритмика и ее апогей в творчестве Гильома де Машо. - В кн. Проблемы музыкального ритма. - М, - 1978. 